\title{
Optimasi Briket Bungkil Jarak Pagar (Jatropha Curcas) Melalui Variasi Tepung Tapioka
}

\author{
Opir Rumape ${ }^{1 *}$, Erni Mohamad ${ }^{2}$, Rindi Antika Mohi ${ }^{3}$ \\ ${ }^{1,2,3}$ Program Studi Pendidikan Kimia, FMIPA Universitas Negeri Gorontalo
}

\section{*Corresponding author:}

email:opir.rumape@ung.ac.id

Received: 18 March, 2019

Accepted: 19 March, 2019

Online : 20 March, 2019
Abstract. This research was aimed to synthesis and charaeterization of bio briquette from jathropa as fuel alternative. It was tested froxmite malysis and through variation of sharch. The res showed that briquette of jathropa head $7,837 \%$ of moisture content, 5,993\% of ash, 50,900\% volatile compounds, density and 7027,322- $6120,711 \mathrm{kal} / \mathrm{g}$ of calorifie value.

Keywords: Jatropha, biobriket characteristics, test proximate, tapioca

Abstrak. Penelitian ini bertujuan untuk mengetahui proses pembuatan briket jarak pagar melalui variasi tepung tapioka sebagai bahan alternatif, melalui tahapan penelitian yang meliputi pembuatan briket yaitu pengeringan, karbonasi, dan pencetakan. Karakterisasi briket meliputi uji proksimasi yakni kadar air, kadar abu, kadar senyawa volatil, kadar karbon terikat, kerapatan dan nilai kalor. Dari hasil uji proksimasi menunjukkan bahwa briket dari bungkil jarak pagar memperoleh ratarata $7,837 \%$. untuk kadar air, rata-rata 5,993\%. untuk kadar abu, ratarata 50,900\% untuk kadar senyawa volatil, 7027,322 $-6120,711 \mathrm{kal} / \mathrm{g}$ untuk nilai kalor.

Kata kunci: Jarak pagar, karakteristik biobriket, uji proksimasi, tepung tapioka

\section{PENDAHULUAN}

Indonesia merupakan negara yang kaya akan sumber daya alam yang sangat berlimpah, baik sumber daya alam yang dapat diperbaharui maupun tidak dapat diperbaharui. Sumber daya alam yang dapat diperbaharui seperti: ekosistem hutan dan ekosistem hewan sedangkan sumber daya yang tidak dapat diperbaharui seperti: minyak bumi, batubara, pertambangan emas, perak dan lain-lain.

Sumber energi alternatif yang dapat diperbaharui di Indonesia relatif banyak, diantaranya biomassa ataupun bahan-bahan limbah organik lainnya. Biomassa ataupun bahanbahan limbah organik lainnya ini dapat diolah dan dijadikan sebagai bahan bakar alternatif, contoh dengan adanya pembuatan briket (Utomo, dkk, 2013).

Tanaman jarak pagar di Indonesia telah tumbuh di berbagai pelosok daerah sebagai pagar pembatas halaman maupun kebun, namun belum ada informasi lengkap yang mendeskripsikan adanya keunggulan dari masing-masing tanaman yang tumbuh di berbagai daerah tersebut untuk mengusahakan tanaman jarak pagar diperlukan bahan tanaman yang memiliki keunggulan genetik yang dicirikan oleh potensi produksi biji tinggi, cepat berproduksi dan beradaptasi luas

terhadap lingkungan yang tidak
menguntungkan.(Santoso, 2011).
Bahan bakar alternative sebagai
pengganti bahan bakar minyak dapat memanfaatkan energi terbarukan seperti biomassa. Biomassa adalah salah satu energi alternatif yang berpotensi sangat besar di Indonesia. Dilain pihak, Indonesia sebagai negara agraris banyak menghasilkan limbah pertanian yang kurang termanfaatkan. Limbah pertanian yang merupakan biomassa tersebut merupakan sumber energi alternatif yang melimpah dengan kandungan energi yang relatif besar. Limbah pertanian tersebut dapat diolah menjadi suatu bahan bakar padat buatan sebagai bahan bakar alternatif yang disebut briket.(Erikson, 2011. dalam Lukum, dkk 2012).

Pembuatan briket dari bahan baku jarak pagar diharapkan dapat mengatasi permasalahan lingkungan juga menjadi solusi dari kelangkaan bahan bakar. Bahan utama yang harus terdapat dalam bahan baku pembuatan briket adalah selulosa, karena semakin tinggi kandungan selulosa maka semakin baik kualitas briket.

Untuk mengoptimalkan penggunaan bahan bakar alternatif sebagai bahan bakar pengganti minyak tanah maka perlu adanya optimalisasi dalam meningkatkan efektifitas dan efisiensi dari bahan bakar aternatif tersebut. Maka dari itu, akan dilakukan penelitian, bagaimana 
pembuatan briket dari bungkil jarak pagar bisa jadi bahan bakar dan dimanfaatkan menjadi benda yang bernilai jual yaitu dengan mengubahnya menjadi energi alternatif.

\section{METODE PENELITIAN}

Bahan tumbuhan yang di-gunakan sebagai sampel penelitian ini adalah bungkil jarak pagar (Jatropha Curcas) yang diperoleh dari Kecamatan pinogaluman Kabupaten Bolaang Mongondow Utara Bahan kimia yang di-gunakan pada penelitian ini adalah air (aquadest) dan lem dari bahan tepung tapioca. Alat yang digunakan pada penelitian ini adalah alat bomb calorimeter, oven, tanur, desikator, mesin pencetak briket, timbangan material, cawan porselin, pengempa manual, timbangan analitik, spatula, stopwatch, ayakan, wadah (Loyang), pengaduk, lumpang dan alu, furnace, peralatan gelas, drum.

Pengumpulan dan pengolahan sampel, pegarangan jarak pagar dan pencetakan briket kemudian dilakukan analisis proksimasi dengan penentuan kadar air, kadar abu, Dekomposisi senyawa volatil, kerapatan, karbon terikat dan nilai kalor.

\section{Analisis proksimasi}

\section{Kadar Air}

Cawan yang sudah dibersihkan, dioven pada suhu $105{ }^{\circ} \mathrm{C}$ selama 2 jam setelah itu didinginkan dalam desikator selama 30 menit, kemudian ditimbang (A gram). Sampel sebanyak 2 gram (gram) dimasukan dalam cawan. Memasukkan ke dalam oven pada suhu $105{ }^{\circ} \mathrm{C}$ minimal 3 jam, didinginkan ke dalam desikator selama 30 menit kemudian di timbangan (C gram). Perhitungan kadar air dengan persamaan 1, sebagai berikut,:

$$
\% \text { Air }=\left(\frac{B-C}{B-A} \times 100 \%\right)
$$

Keterangan:

Berat cawan kosong sebagai berat $(A)$, berat cawan dan sampel sebelum dioven sebagai berat (B), dan berat cawan dan sampel yang sudah dioven sebagai berat (C) (Erikson, 2011).

\section{Kadar abu}

1. Panaskan cawan porselin dalam oven pada suhu $105^{\circ} \mathrm{C}$ selama 1 jam, lalu didinginkan dalam eksikator kemudian ditimbang.

2. Timbang contoh lalu masukkan dalam tungku pengabuan pada suhu $550^{\circ} \mathrm{C}$ sampai contoh menjadi abu.

3. Kemudian didinginkan dalam eksikator dan ditimbang, sehingga berat bootnya didapatkan :

$$
\text { Kadar abu }(\%)=\frac{D}{B} \times 100 \%
$$

Dengan :

$\mathrm{D}=$ Berat abu $(\mathrm{g})$

$\mathrm{B}=$ Berat sampel sebelum pengabuan $(\mathrm{g})$

\section{Nilai Kalor}

Nilai Kalor adalah energi yang dihasilkan dari pembakaran suatu zat yaitu arang briket dengan menggunakan alat bomb kalorimeter (Perry's, 6th ed).Untuk mendapatkan perhitungan yang absolut dan nilai kalori yang cukup beberapa faktor yang mempengaruhi yang harus diperhatikan yaitu kadar air dan kerapatan/porositas. Maka dari itu, untuk menentukan dapat ditentukan dengan bomb kalorimeter yang ada di Laboratorium Kimia Fisik/Anorganik Universitas tadulako.

\section{Kerapatan $(\rho)$}

Pengujian dilakukan dengan mendeterminasi beberapa rapat masa briket melalui perbandingan beberapa rapat massa briket melalui perbandingan antara massa briket dan besarnya dimensi volumetrik jarak pagar.

$$
\begin{aligned}
& \text { (kerapata Briket) } \rho=\frac{m}{V t o t} \\
& \text { (volume Briket) } V \text { tot }=\pi r^{2} t
\end{aligned}
$$

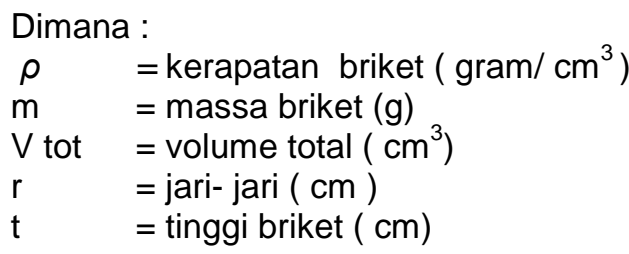

\section{Dekomposisi Senyawa Volatile}

Cawan perselin yang sudah dibersihkan dioven pad suhu $105^{\circ} \mathrm{C}$ selama 2 jam, mendinginkan dalam desikator selama 30 menit kemudian

ditimbang (A gram), sampel sebanyak 2 gram ( $B$ gram) dimasukan kedalam cawan. Selanjutnya m emanaskan pada suhu $650^{\circ} \mathrm{C}$ selama 10 menit, didinginkan dalam desikator selama 30 menit kemudian ditimbang ( $\mathrm{C}$ gram).

Dekomposisi senyawa volatil $=\left(\frac{B-C}{B} X 100 \%\right)$

Keterangan:

Berat sampel sebelum dioven sebagai berat (B), dan berat sampel yang sudah di furnace sebagai berat (C) (Erikson, 2011).

\section{Karbon Terikat}

Karbon Terikat dihitung dari 100\% dikurangi dengan kadar air lembab dikurangi kadar abu,dikurangi kadar dekomposisi senyawa volatil Karbon Terikat $(\%)=100 \%$ - (kadar air + Kadar $\mathrm{Abu}+$ dekomposisi senyawa volatil) (Erikson, 2011).

\section{HASIL DAN PEMBAHASAN}

Berikut data hasil spesifikasi variasi briket arang bungkil jarak pagar seperti pada tabel 1 sebaga berikut, 
Tabel 1 Hasil spesifikasi variasi briket arang bungkil jarak pagar

\begin{tabular}{ccccc}
\hline No & Kode Variasi & $\begin{array}{c}\text { Massa } \\
\text { (gram) }\end{array}$ & $\begin{array}{c}\text { Diameter } \\
\text { (cm) }\end{array}$ & $\begin{array}{c}\text { Tinggi } \\
(\mathrm{cm})\end{array}$ \\
& & $\mathrm{M}$ & $\mathrm{D}$ & $\mathrm{T}$ \\
\hline 1 & $1: 2$ & 22,213 & 4 & 3 \\
2 & $1: 3$ & 25,050 & 4 & 3 \\
3 & $1: 4$ & 26,520 & 4 & 3 \\
4 & $1: 5$ & 24,295 & 4 & 3 \\
\hline
\end{tabular}

Data penelitian dibandingkan dengan standar kualitas briket arang Jepang, Inggris, Amerika yang ada dipasaran untuk masingmasing sifat fisik dan kimia yang diuji. Maka adapun data hasil pengukuran sifat fisik dan kimia yang diperoleh yaitu dapat dilihat pada tabel 2 sebagai berikut,

Tabel 2 Data hasil pengukuran sifat fisik dan kimia briket arang bungkil jarak pagar

\begin{tabular}{|c|c|c|c|c|c|}
\hline \multirow[t]{2}{*}{ No } & \multirow[t]{2}{*}{ Jenis uji } & \multicolumn{4}{|c|}{$\begin{array}{c}\text { Komposisi Bahan Baku Arang } \\
\text { dan Perekat }\end{array}$} \\
\hline & & $1: 2$ & $1: 3$ & $1: 4$ & $1: 5$ \\
\hline 1 & $\begin{array}{l}\text { Kadar Air } \\
(\%)\end{array}$ & 8,787 & 7,605 & 7,337 & 7,620 \\
\hline 2 & $\begin{array}{l}\text { Kadar } \\
\text { Abu (\%) }\end{array}$ & 7,443 & 6,533 & 5,750 & 4,246 \\
\hline 3 & $\begin{array}{c}\text { Kadar } \\
\text { Volatile } \\
\text { (\%) }\end{array}$ & $\begin{array}{c}38,54 \\
1\end{array}$ & $\begin{array}{c}30,04 \\
6\end{array}$ & 30,030 & $\begin{array}{c}30,31 \\
2\end{array}$ \\
\hline 4 & $\begin{array}{c}\text { Kadar } \\
\text { Karbon } \\
\text { Terikat } \\
(\%)\end{array}$ & $\begin{array}{c}45,21 \\
2\end{array}$ & $\begin{array}{c}55,81 \\
5\end{array}$ & 56,882 & $\begin{array}{c}57,82 \\
0\end{array}$ \\
\hline 5 & $\begin{array}{l}\text { Kerapata } \\
\text { n (\%) }\end{array}$ & 0,58 & 0,63 & 0,70 & 0,64 \\
\hline 6 & $\begin{array}{c}\text { Nilai } \\
\text { Kalor (\%) }\end{array}$ & $\begin{array}{c}6619 \\
235\end{array}$ & $\begin{array}{c}6965 \\
215\end{array}$ & $\begin{array}{c}7027,3 \\
22\end{array}$ & $\begin{array}{c}6120 \\
711\end{array}$ \\
\hline
\end{tabular}

\section{Kadar Air}

Kadar air briket diharapkan serendah mungkin agar nilai kalornya tinggi dan mudah dinyalakan. Kadar air mempengaruhi kualitas briket yang dihasilkan. Semakin rendah kadar air semakin tinggi nilai kalor dan daya pembakarannya. Sebaliknya, kadar air yang tinggi menyebabkan nilai kalor yang dihasilkan akan menurun, karena energi yang dihasilkan banyak terserap untuk menguapkan air.

Arang mempunyai kemampuan untuk menyerap air yang sangat besar dari udara disekelilingnya. Kemampuan dalam menyerap air dipengaruhi oleh luas permukaan dan pori-pori arang dan dipengaruhi oleh kadar karbon terikat yang terdapat pada briket tersebut. Dengan demikian, semakin kecil kadar karbon terikat pada briket arang, kemampuan briket arang menyerap air dari udara sekililingnya semakin besar.( Earl, 1974 dalam Rustini, 2004 ).
Nilai kadar air terendah adalah 7,337\% yang terdapat pada briket arang bungkil jarak pagar dengan variasi 1:4. Nilai kadar air tertinggi adalah $8,787 \%$ yang terdapat pada briket arang bungkil biji jarak pagar dengan variasi 1:2, hal ini disebabkan karena setiap variasi memiliki jumlah pori-pori yang berbeda sehingga kemampuan menyerap airnya pun berbeda pula. Selain itu ada juga yang menunjukkan bahwa faktor jenis bahan baku berpengaruh sangat nyata terhadap kadar air briket arang yang dihasilkan.(Hendara djeni.2007)

Kandungan air berhubungan dengan penyalaan awal bahan bakar, makin tinggi air makin sulit penyalaan bahan bakar tersebut, karena diperlukan energi untuk menguapkan air dari bahan bakar, Karena itu untuk menguapkan air dari briket maka perlu dilakukan teknik pengeringan 2-3 jam dalam sehari, sehingga selain mengurangi kadar air juga mengurangi retakan-retakan pada briket. Hal ini akan berpengaruh besar pada kualitas briket itu sendiri.

Dalam penelitian ini kadar air dari briket arang bungkil biji jarak pagar mempunyai ratarata sebesar 7,837 \%. Harga ini memperlihatkan bahwa kandungan kadar air dalam briket arang bungkil jarak pagar lebih rendah dari briket jepang $(6-8) \%$ dan lebih tinggi dari briket USA $(6,2) \%$, dan briket Inggris. $(3,6) \%$, dan lebih tinggi dari briket Standar Nasional Indonesia (8)\%, dan sudah sesuai dengan standar briket Energi Sumber Daya Mineral (ESDM) $(<15)$.

\section{Kadar Abu}

Abu merupakan bagian tersisa dari proses pembakaran yang sudah tidak memiliki unsur karbon lagi. Unsur utama abu adalah silika dan pengaruhnya kurang baik terhadap nilai kalor yang dihasilkan. Semakin tinggi kadar abu maka semakin rendak kualitas briket Karena kandungan abu yang tinggi dapat menurunkan nilai kalor briket arang.

Kadar abu dengan rata-rata yang diperoleh adalah 5,993 \%. Nilai kandungan (kadar abu) rata-rata ini lebih rendah dari Standar Briket USA $(8,3) \%$. Lebih tinggi standar briket inggris (810)\%, Briket SNI (8-10) Dan sudah memenuhi standar briket jepang(5-7)\%.

Kadar abu terendah terdapat pada briket arang bungkil jarak pagar variasi 1:5 yaitu sebesar 4,246\%, sedangkan kadar abu tertinggi terdapat pada briket arang dari arang bungkil jarak pagar, variasi $1: 2$ yaitu sebesar $7,443 \%$. Nilai kadar abu ini jika dibandingkan dengan kualitas briket arang Amerika (18\%), Jepang (3 $6 \%)$, Inggris (8-10\%), kadar abunya tidak jauh berbeda dan sudah sesuai Standar Nasional Indonesia (8-10)\%. Hal ini menunjukan bahwa faktor jenis bahan baku berpengaruh sangat nyata terhadap kadar abu briket yang akan dihasilkan. (Hendara djeni.2007) 
Faktor jenis bahan baku sangat berpengaruh terhadap tinggi rendahnya kadar abu briket arang yang dihasilkan. Hal ini dikarena bahan baku yang digunakan me-miliki komposisi kimia dan jumlah mineral yang berbeda-beda sehingga meng- akibatkan kadar abu briket arang yang dihasilkan berbeda pula (Hendra dan Winarni,2003 dalam hendra, 2007).

\section{Kadar Zat Volatile}

Senyawa volatile adalah zat yang dapat menguap sebagai hasil dekomposisi senyawa senyawa didalam arang selain air. Kandungan kadar zat menguap yang tinggi didalam briket arang akan menimbulkan asap yang lebih banyak pada saat briket dinyalakan, hal ini disebabkan oleh adanya reaksi antara karbon monoksida (CO) . (Hendra dan Pari, 2000 dalam Rustini, 2004).

Hasil sidik ragam menunjukkan bahwa baik konsentrasi perekat maupun jenis perekat (tepung tapioka) memberikan hasil tidak beda nyata terhadap kadar zat menguap. Kecenderungan nilai kadar zat menguap yang relative tetap pada briket dengan konsentrasi perekat dan jenis perekat yang berbeda.

Kandungan rata-rata senyawa volatil dalam briket arang bungkil jarak pagar adalah dengan rata-rata $32,232 \%$, ini lebih tinggi dari nilai pada standar Briket jepang, briket Inggris, SNI, maupun Briket USA.

Semakin banyak kandungan volatile matter pada biobriket maka biobriket tersebut akan semakin mudah untuk terbakar dan menyala (Samsul, 2004 dalam Erikson 2011). senyawa volatil dalam bahan bakar berfungsi hanya untuk menstabilkan nyala api, mengurangi timbulnya asap dan percepatan pembakaran arang. Hal ini dikarenakan kadar senyawa volatil dipengaruhi oleh suhu dan waktu pengarangan, semakin besar suhu dan waktu maka semakin banyak kadar senyawa volatil yang terbuang selama proses pengarangan sehingga kandungan dekomposisi senyawa volatil akan semakin kecil (Gafar dkk., 1999 dalam Rustini 2004).

Menurut Hendra, (2007) dalam Erikson, (2011). Tinggi rendahnya senyawa volatil yang dihasilkan dipengaruhi oleh jenis bahan baku seperti karbon monoksida, sehingga perbedaan jenis bahan baku berpengaruh terhadap nilai kadar senyawa volatil pada setiap briket arang.

\section{Kadar Karbon Terikat}

Kandungan karbon terikat pada briket arang dipengaruhi oleh nilai kadarabu dan kadar dekomposisi senyawa volatil. Kadar karbon terikat akan bernilai tinggi apabila nilai kadar abu dan kadar dekomposisi senyawa volatil rendah. Briket yang baik memiliki kadar karbon tinggi (Erikson, 2011).

Kandungan karbon terikat rata-rata di dalam briket bungkil jarak pagar dengan perekat tepung tapioka adalah 53,932\%, nilai ini menunjukkan bahwa nilai kabon terikat pada briket arang bungkil biji jarak pagar berada di bawah standar briket jepang, briket inggris, briket USA, dan SNI.

Kadar karbon terikat terendah 45,212\% terdapat pada briket arang dengan variasi perbandingan abu arang dan perekat tepung tapioka (1:2) bungkil biji jarak pagar dan kadar karbon terikat tertinggi $(57,820 \%)$ terdapat pada briket bungkil biji jarak pagar dengan variasi perbandingan abu arang dan bahan perekat tepung tapioka (1:5). Keberadaan karbon terikat di dalam arang dipengaruhi oleh nilai kadar abu dan dekomposisi senyawa volatile. Karbon terikat mempunyai peranan yang cukup penting untuk m enentukan kualitas arang karena akan mempenga ruhi besarnya nilai kalor yang dihasilkan. (Diah Sundari Wijayanti (2009), dalam Erikson, (2011).

\section{Nilai Kalor}

Nilai kalor adalah menjadi parameter mutu paling penting bagi briket arang sebagai bahan bakar sehingga nilai kalor sangat menentukan kualitas briket arang. Semakin tinggi nilai kalor bakar briket arang, maka semakin tinggi pula kualitas briket yang dihasilkan.Nilai kalor sangat dipengaruhi oleh kadar abu briket arang. Semakin rendah kadar abu dan kadar air pada briket arang maka akan meningkatkan nilai kalor bakar briket arang yang dihasilkan.

Nilai kalor rata-rata di dalam arang briket bungkil jarak pagar dengan perekat tepung tapioka adalah $6683,12 \%$, nilai ini menunjukkan bahwa nilai kalor pada briket arang bungkil biji jarak pagar sudah sesuai dengan SNI dan ESDM.

Variasi perekat sangat berpengaruh terhadap nilai kadar kalor. Semakin banyak perekat maka semakin banyak abu yang di hasilkan, nilai kalor sangat dipengaruhi oleh kadar abu briket arang. Semakin rendah kadar abu briket arang maka akan meningkatkan nilai kalor bakar briket arang yang dihasilkan. Nurhayati (1974) dalam Erikson (2002).

Terlihat dari Tabel diats bahwa variasi yang memiliki nilai kalor yang tinggi yaitu perbandingan antara 1:4 yaitu 7027,332 kal/gram. Hal ini disebabkan kadar karbon terikat pada briket arang jauh lebih besar dan kadar zat menguapnya jauh lebih kecil, sehingga nilai kalor yang dihasilkan briket arang pun jauh lebih tinggi. Sedangkan nilai kalor yang terendah dari briket arang bungkil jarak pagar yaitu variase 1:5 dengan nilai kalor 6120,7 kal/gram.

Nilai kalor briket arang yang dihasilkan berkisar antara 7027,322 -6120,711 kal/g dengan rata-rata sebesar $6683,120 \mathrm{kal} / \mathrm{g}$. Hasil ini sebagian telah memenuhi kualitas briket arang Jepang (6.000-7.000 kal/g), Indonesia (6.814,11 $\mathrm{kal} / \mathrm{g})$, Amerika(6,230kal/g), SNI, ESDM dan sudah memenuhi kualitas briket arang Inggris $(7,289 \mathrm{kal} / \mathrm{g})$. 
Adapun faktor jenis bahan baku sangat mempengaruhi besarnya nilai kalor bakar briket arang yang dihasilkan. Kadar karbon terikat yang tinggi akan menyebabkan tingginya nilai kalor bakar briket arang. Tiap bahan baku memiliki kadar karbon terikat yang berbeda-beda sehingga mengakibatkan nilai kalor bakar yang berbedabeda pula untuk tiap jenis bahan baku briket arang. Bahan baku yang memiliki kadar karbon terikat yang tinggi akan menghasilkan nilai kalor bakar briket arang yang tinggi pula. Menurut Hendra dan Winarni (2003) semakin tinggi kadar karbon terikat akan semakin tinggi pula nilai kalornya, karena setiap ada reaksi oksidasi akan menghasilkan kalori.

\section{Uji Kerapatan Briket}

Kerapatan berpengaruh terhadap kualitas briket arang, briket arang dengan kerapatan yang tinggi dapat meningkatkan Nilai kalor bakar briket arang. Besar kecilnya kerapatan dipengaruhi oleh ukuran dan kehomogenan arang penyusun briket arang tersebut. Semakin tinggi keseragaman ukuran serbuk arang maka akan menghasilkan briket arang dengan kerapatan dan keteguhan yang semakin tinggi pula (Nurhayati, 1983 dalam Rustini, 2004).

Kerapatan terendah sebesar $0,58 \mathrm{~g} / \mathrm{cm}^{3}$ diperoleh pada briket dengan variasi perekat $1: 2$ sedangkan kerapatan tertinggi sebesar 0,70 $\mathrm{g} / \mathrm{cm}^{3}$ dengan variasi 1:4 semakin banyak perekat yang digunakan maka semakin baik kerapat briket,tetapi tergantung tekstur dari sampael yang digunakan, bungkil biji jarak pagar memiliki bahan tekstur kerapat yang rendah maka pengunakan petekat yang baik sesuai berat sampel yang digunakan.

Uji kerapatan briket arang bungkil biji jarak pagar lebih rendah dengan kerapatan ratarata sebesar $0,63 \mathrm{~g} / \mathrm{cm}^{3}$ dari standar briket jepang dengan kerpatan 1,0 $-1,2 \mathrm{~g} / \mathrm{cm}^{3}$, standar briket amerika (USA) dengan kerapat 1, - 1,2 $\mathrm{g} / \mathrm{cm}^{3}$, tapi sudah memenuhi mutu standar briket inggris dengan kerapaant $0,46-0,84 \mathrm{~g} / \mathrm{cm}^{3}$.

\section{KESIMPULAN}

Dari hasil penelitian ini maka dapat disimpulkan bahwa proses pembuatan briket arang bungkil jarak pagar dengan bentuk briket yang dibuat selindres yaitu:

1. Pembuatan briket bungkil jarak pagar menghasilkan nilai kalor dari briket arang berkisar $7027,322-6120,711 \mathrm{kal} / \mathrm{gram}$. Briket arang bungkil biji jarak pagar memenuhi standar mutu briket yaitu Standar Nasional Indonesia (SNI), kadar air 7,337\%, kadar abu 5,993 \%, dan dekomposisi senyawa volatile $32,232 \%$ yang tinggi sehingga briket bungkil jarak pagar memiliki kualitas yang baik.

2.Pengujian analisi proksimasi sifat fisik dan kimia, maka briket arang bungkil jarak pagar yang miliki kualitas yang baik adalah briket dengan perbandingan 1:4 yang memenuhi mutu standar briket yang beredar dipasaran dan memiliki keunggulan nilai kalor yang tinggi, dibandingkan dengan briket standar Standar Nasional Indonesia (SNI), impor, Inggris, standar briket Jepang dan Amerika,

\section{DAFTAR PUSTAKA}

Bambang B. Santoso, Bambang S.Purwok. 2011. Karakter dan kandungan minyak biji jarak pagar (jatropha curcas l.) Genotipe Nusa Tenggara Barat. Fakultas Pertanian UNRAM, Jurusan Agronomi dan Hortikultura Fakultas Pertanian IPB.

Erikson Sinurat. 2011. Studi Pemanfaatan Briket Kulit Jambu Mete Dan Tongkol Jagung Sebagai Bahan Bakar Alternatif. Skripsi Jurusan Mesin Fakultas Teknik Universitas Hasanuddin Makassar

Hendra,djani.2011.pemanfaatan eceng gondok untuk bahan baku briket sebagai bahan bakar alternatif.

Rustini, 2004. Pembutan Briket Arang Dari Serbuk Gergaji Kayu Pinus Dengan Penambahan Tempurung Kelapa.skripsi. Jurusan Teknologi Hasil Hutan. Fakultas Kehutanan. Institu Pertanian Bogor.

Santosa dkk. 2010. Studi variasi komposisi bahan penyusun briket dari kotoran sapi dan limbah pertanian. Jurusan Teknik Pertanian, Fakultas Teknologi Pertanian Universitas Andalas Kampus Limau Manis, Padang - 25163.

Sinurat, Erikson. 2011. Studi Pemanfaatan Briket Kulit Jamu Mente dan Tongkol Jagung Sebagai Bahan Bakar Alternatif. Tugas Akhir Diajukan KepadaFakultas Teknik Universitas Hasanudin. Makassar.

S.W. Tukimin Dan Elna Karmawati. 2012. Pengaruh Minyak Bungkil Biji Jarak Pagar Terhadap Mortalitas Danpeneluran Helicoverpa armigera Hũbner 